\title{
REVIEW OF VARIOUS DELAY CAUSING FACTORS AND THEIR RESOLUTION BY APPLICATION OF LEAN PRINCIPLES IN INDIA
}

\author{
Shumank DEEP' ${ }^{1}$, Mohd ASIM ${ }^{2}$, Mohd Kashif KHAN ${ }^{3}$ \\ ${ }^{1}$ School of Architecture and Built Environment, University of Newcastle, Callaghan 2308 \\ NSW, Australia \\ ${ }^{2,3}$ Department of Civil Engineering, Integral University, P.O Bas-ha Dasauli Kursi Road \\ Lucknow 226026 UP, India \\ Corresponding authore-mail: shumank2012@gmail.com
}

\begin{abstract}
Practically speaking, not all real estate construction projects are accomplished in the defined span and within budget. Various factors responsible for occurrence of delays are one of the long-standing issues in the field of real estate. Delays make contractors endure productivity loss, cause high disturbance expenses, and prolongation costs. The aim of the research is to summarize several delay causing factors, which are observed in the execution of previous real estate construction projects. It then proposes implementation of standard prevention procedures to minimize delays. Time effect examination is the approach to evaluating and allotting the upshots of delays or changing a venture schedule. This review sets execution framework of the two sub-principles of the Toyota Way attributes known as philosophy sub-principles and process subprinciples to guide real estate construction businesses in their lean change to delay free real estate construction work. These are implemented after investigating the critical factors responsible for delays in the delayed projects by comparing their as-planned schedules with the adjusted schedules. Methods used in the research include structured surveys and content analysis, which is performed after collection of quantitative data from the respondents. The lean construction principles will be designed and provided to clients to be productive in performing work packages on their scheduled time with minimum possibility of time overrun.
\end{abstract}

Keywords: Construction, delays, lean construction, lean principles, real estate.

\section{INTRODUCTION}

The objective of all stakeholders of the development ventures - owners, contractual workers, specialists and advisors in either public or private sector is to release the venture effectively within the scheduled timeframe, according to the arranged spending plan, ensuring top quality and in the most secure way. However, postponement is a noteworthy limitation of the construction industry internationally (Lovejoy, 2004; Etges et al., 2012). It has been concluded that most activities, for the most part vast and complex ones, are not always completed effectively. 
Mathematically, construction delays are the function of time. Delay can be defined as a time extension in a project having further impact on the duration resulting in a cost overrun. Postponements can cause various consequences, i.e. raise concerns amongst proprietors and contractual workers leading to discontent, expanded costs, loss of efficiency and income, and contract termination. Regulatory requirements can be met recognizing these causes and employing productive and successful venture administration procedures and methods to oversee and control the tasks. The Toyota Way Model is utilized to minimize probability of occurrence of postponement in construction industry by implementing its various attributes in the execution of construction projects. It is essential to know the determinants of the Toyota Way Model with regard to their capacity to limit a deferring circumstance.

\section{LITERATURE REVIEW}

In Northern India, the majority of real estate construction projects face the problem of time overrun, which signifies delays in construction projects (Asim, Shumank and Aqeel, 2017). Delays are a common phenomenon regardless of whether the project is simple or complex. Kazaz et al. (2012) analyzed the reasons for construction delays and studied their impacts on the time frame. In order to mitigate the impacts of delays on the productivity and project performance it is necessary to strategically plan the project (Yang et al., 2012; Doloi, H. et al., 2012). The advantages of pre-project arrangement incorporate expanded benefit, lessened hazard, and superior quality (Barker et al. 2004; González et al. 2008; Hanna and Skiffington 2010; Asim, Deep, and Aqeel, 2017). Exhaustive scheduling influences to a greater extent the productivity during initiation, design and development stages (Chang et al., 2010; Yang and Wei, 2010; Deep, Singh, and Aqeel, 2016). This finding is supported by Thomas and Ellis (2007), who utilized straightforward preextend arrangement strategies to diminish preparatory development length by up to $30 \%$. Hanna and Skiffington (2010) argued that expanded construction arrangement enables the temporary worker to be more proactive than receptive with respect to basic elements that influence a venture. As per Gibson et al. (2006), strategic planning of project could lead to enhanced project result, more prominent client fulfilment, and decreased venture cost and term. Therefore, distinguishing and testing for noteworthy contrasts in the effects of the basic achievement figures with respect to time, cost, and quality are crucial in managing these elements in preextend arrangement as an approach to secure the best project result. In development industry, deferral could be characterized as the time overrun beyond the contract date (Assaf and Al-Hejji, 2006).

A venture consists of a series of tasks. The deferred task can bring about postponements in the completion of the venture. Investigation of delays is utilized to identify the cause(s) of deferral. An extension of time relieves the contractor from the liability for damages (Lowsley and Linnett, 2006). The examination of postponements in development tasks is troublesome and convoluted in view of a large number of individual exercises that must be managed, even in a generally straightforward venture. A medium-sized venture may comprise several exercises, a considerable lot of which may occur at various circumstances and at the lengths 
different from those initially arranged. A few exercises might be deferred or quickened, and such changes may in part or completely influence the venture completion date. In the investigation of Alaghbari et al. (2007), deferral is by and large recognized as the most widely recognized, exorbitant, unpredictable and dangerous issue experienced within the development ventures. Recognizable proofs of the elements that add up to postponements have been considered by various analysts worldwide. Postponement is a circumstance when a temporary worker, advisor, and customer together or separately add to the non-finishing of the venture in the stipulated contract period. In India, Iyer and Jha $(2005,2006)$ distinguished the following project achievement and disappointment properties and their inert property disappointment traits: strife among project members, obliviousness and absence of information, poor particular project qualities and absence of collaboration, adverse financial and climatic condition, hesitance in convenient choice, forceful rivalry at delicate stages, short offer planning time. A review made by IHS Global (2009) maintains that the Indian development industry is profoundly divided. This is partly attributed to the fact that for most ventures, there are no long lasting connections between the temporary workers and customers. For example, government workplaces, such as the National Highway Authority of India (NHAI), do not provide any preferences to the authoritative specialists that have worked with them already. Since the industry needs economies of scale, smaller players may have better cost structures in view of lower overhead costs.

\subsection{Causes of Delays}

Scientists have analyzed many reasons for postponement in the development business. Table 1 summarizes several reviews conducted from 1971 to 1994.

Table 1. Outline of Past Investigation of the Origin of Delays in Construction Projects

\begin{tabular}{|l|l|l|}
\hline Researcher & Country & Critical postpone variables \\
\hline $\begin{array}{l}\text { Baldwin et al. } \\
(1971)\end{array}$ & United States & $\begin{array}{l}\text { Meteorological changes, deficiencies of manual drive } \\
\text { supply, subcontracting framework }\end{array}$ \\
\hline Arditi et al. (1985) & Turkey & $\begin{array}{l}\text { Inadequate assets, delay in configuration work, } \\
\text { monetary troubles confronted by open offices and } \\
\text { temporary workers, hierarchical challenges, changes } \\
\text { in work order }\end{array}$ \\
\hline Assaf et al. (1995) & Saudi Arabia & $\begin{array}{l}\text { Delays in installments to temporary workers, } \\
\text { deficiencies of work supply, poor workmanship, } \\
\text { changes in requests }\end{array}$ \\
\hline $\begin{array}{l}\text { Okpala and } \\
\text { Aniekwu (1998) }\end{array}$ & Nigeria & $\begin{array}{l}\text { Inability to pay for finished works, poor contract } \\
\text { administration }\end{array}$ \\
\hline $\begin{array}{l}\text { Dlakwa and Culpin } \\
\text { (1990) }\end{array}$ & Nigeria & $\begin{array}{l}\text { Delays in installments by organizations to temporary } \\
\text { workers }\end{array}$ \\
\hline Semple et al.(1994) & Canada & $\begin{array}{l}\text { Increases in the extent of work, harsh climate, } \\
\text { inadequate resources }\end{array}$ \\
\hline
\end{tabular}

Source: developed by the authors, on the basis of previous studies. 
Table 1 showed the outline of Past Investigation of the origin of delays in construction projects.

\section{METHODOLOGY}

The methodology used in the present study is includes analysis of communitybased real estate projects through juxtaposing as-planned schedules and as-built adjusted schedules with delay statistics, 100 in gross, to identify various determinants influencing the timely conveyance of construction projects. 57 determinants are identified within the scope of knowledge and codified into 7 brackets. The rate of occurrence of the examined determinants is manifested in the incidence based clustered column chart. The examination brings about pinpointing to what extent the lean guidelines are met; further their significance for organizations or undertakings is investigated from the point of view of the respondents with expected advantages in view of delay prevention attributes for real estate construction industry regarding the execution of two unique principles of the Toyota Way guidelines. These inputs are obtained from both the review and meetings from both the financial specialists' and contractors' perspective in the arranging, contracting and development of a project. It is imperative to ponder what methodologies ought to be adopted to overcome the analyzed shortcomings, particularly with respect to the structure of balance attached framework to reduce occurrence of delays.

\subsection{Need for Research}

Construction ventures in Lucknow Region (India) are characterized by four unsafe execution features, to be specific, quality, efficiency, profitability and venture administration. With a specific goal to promote serviceably of all execution aspects, morals of Toyota Way Model can be adopted. In genuine authorization, it appears that no single construction firm has completely shown its capacity, limit, or readiness to execute every standard of Toyota Way Model. A requisite is to apply Toyota management postulates to real estate construction firms as an anti-delay remedy to ameliorate adverse effects of deferrals within each of the following attributes: the contribution of staff (manpower), the contribution of materials and machines.

\subsection{Research Design}

The study examines the strategies that have been used in this exploration. The target populace consists of contractual workers, financial specialists and specialized staffs of construction ventures.

\subsection{Questionnaire Outline}

A questionnaire survey is prepared after analyzing 100 work schedules to gain perspective and understanding based on the relative importance index ascribed by the skillful respondents considering construction delays and the opportunities to adopt Toyota Way sub-principles in real estate construction industry. By doing so, 
it is envisaged to narrow the gap between the existing Indian real estate construction practices and application of the Toyota Way philosophy for reduction of delays. The survey was conducted in the period of four months i.e. September, 2016, to December, 2016.

\subsection{Respondent Background}

The questionnaire was distributed among investors, contractors and project managers of real estate construction firms, 350 in total. 275 responses were received, 68, 125 and 82 responses from engineers, contractors and project managers, respectively. All respondents had average working experience of ten years. Their responses were deployed for grouping the expected benefits in enacting Toyota Way postulates in the real estate construction industry.

\section{TIME IMPACT ANALYSIS, DEFINITIONS AND USES}

The time impact analysis is considered in numerous industry publications dedicated to delay analysis methodologies for determining the extent of impact from a potential delay event. For gathering delay factor information using time impact method it is required to have an as-arranged time table to characterize a temporary worker's unique arrangement. As-fabricated calendar mirrors the genuine progression of occasions that occurred in the course of execution of the venture, qualification plans comprise either stretched out as-arranged timetables (i.e. the as-arranged calendar with specific classes of postpones included) or crumpled as-assembled timetables (i.e. the as-manufactured calendar with specific classes of postpones excluded), and, finally, balanced timetable is used for evaluation and distinguishing proof of effect of timetable changes on the venture. It is helpful in identifying the impacts of various types of deferrals on the venture culmination date. The objective of the precise time effect examination approach is to gain full understanding of the genuine impact of occasions separately and together, and to assess the impact of progressing deferrals.

\section{INTRODUCTION TO THE TOYOTA WAY ATTRIBUTES}

Lately, the construction organizations have continuously initiated employing the lean characteristics in order to decrease probability of cost and time overrun in construction activities. Up until this point, most organizations have just centered on the utilization of lean attributes and not very many have begun implementing the entire lean endeavor change. Lucknow organizations have three distinct viewpoints towards lean characteristics. Firstly, many organizations have asserted that they are lean organizations since they have effectively actualized 5-S exercises, or and so on, yet they have neglected the interrelationships between numerous tools ( $\mathrm{Gao}$ and Low, 2014). Furthermore, many organizations believe that delays occur because of acts of God and lean principles will not stop delays. Finally, a few organizations feel that they already completed their lean change in the previous years.

Promoting the usage of the lean attributes by the Indian construction organizations is imperative as rationality of this approach can possibly help take 
care of the issues, which plaque the land construction enterprises. The main postulate of lean construction philosophy is "Construct your administration choice in light of the long haul theory, even to the detriment of here and now financial objectives". Sometimes either a temporary worker or an outsider causes delays in construction activities to gain more benefit. In any case, it must not be the driving reason for a contractual worker or the proprietor. The technique of "steadiness of reason" should be employed for development in the offers of deliverables and subsequently benefits (feeling of purpose). To prevent delays during construction work/designing stage, a construction association should not reject its representatives on account of a brief downturn and it should support a long haul association with the providers (long haul perspectives). Construction industry should operate on the premise "how do we do it without anyone's help" and develop confidence. Confidence helps in creating center intensity. The administration attempts to guarantee that all offices understand their dual roles, to be specific, that they are the clients of the past operation as well as the providers to the following operations downstream. With a specific goal to dodge delays caused by the lack of correspondence and insufficient manual operation, stacking and emptying certain hardware construction assets such as gear, works, machines should be arranged around the outline of a u-shape, permitting workers to stroll the shortest span from task to task and accomplish other physical works. It will facilitate communication.

The venture is postponed and the spirit of the workers plunges on account of non-payment or sporadic payment of wages. Subcontractors and providers of materials and segments and their workers are influenced. Excessive workload imposed on labor, staff and equipment reduces their efficiency and further rate of performing work slows down due to sickness. In this case, adverse staff health conditions due to overwork are common and so it becomes a barrier to construction process. Institutionalized undertakings are the establishments that monitor whether the projects act according to the established plan; they suggest that all works ought to be specified in detail regarding timing, substance, grouping and result. Institutionalized work requires distinguishing the repeatable components of a procedure, surveying the ideal approach to apply those components, building up a comprehensive technique to guarantee the execution of those components and after that applying the dependable strategy as per a required time. Visual control in construction is vital due to numerous factors namely site conditions, available tools and techniques and relation between contracting that dramatically constrain monitoring of work at construction site. Fundamentally, visual administration practices can be arranged into various layers of visual working environment system, to be specific, visual request, visual benchmarks, visual measures and controls, and visual assurances. Real estate associations, which are still rather an exception that the norm, develop serious plans to be on the forefront of innovation. Any new technology being implemented as part of innovation must focused on improving the qualities of both organization and individuals.

Building specialists have introduced various practices in the desire to upgrade the level of performance in the industry, which is known for the force with it accelerates the productivity of construction. 


\section{DATA PROCESSING}

The as-planned schedules and as-built schedules of 100 real estate projects have been juxtaposed to account for the aftermath of all-inclusive delays on as-planned conveyance of the projects. Fig. 1 shows comparison of as-planned schedules with as-built schedules of different projects, 100 in gross, which are studied as the abscissa, and their related time extend as the ordinate. The blue shading represents their as-arranged lengths whereas red shading represents their balanced spans because of deferrals. The distinction between their terms has been compared (most extreme 252-402) and is displayed graphically in Fig. 1. Additionally, the differences between as-planned and as-built schedules of a project manifest time overrun. The scope of time overrun of the projects due to delays is demonstrated in Fig. 2 and is known as time impact study. The rate of occurrence of the examined determinants is presented in seven frequency-based clustered column charts as shown in Figs. 3 to 9 and the most critical delay causing factors are grouped in separate cases. Fig. 3 demonstrates the recurrence of eight delay variables that are found in the investigation of 100 balanced timetables. The most distinct recurrence is recorded for the "change of scope" The solution is to minimize the change of the scope of work. Ten variables are determined as contractor-related delay factors. More than sixty real estate projects endure these ten variables with little distinction, as it can be seen in Fig. 4. These ten variables should be carefully considered by contractors in order to restrict the odds of postponements independent from anyone else. Fig. 5 reflects nine design-related delay components. Absence of construction equipment plays a significant role in time delays, although other equipment-related components are minor and are found in a smaller number of cases, as it can be seen in Fig. 6. Fig. 7 indicates labor-related delay variables; Fig. 8 portrays six determinants identified with compensable deferrals.

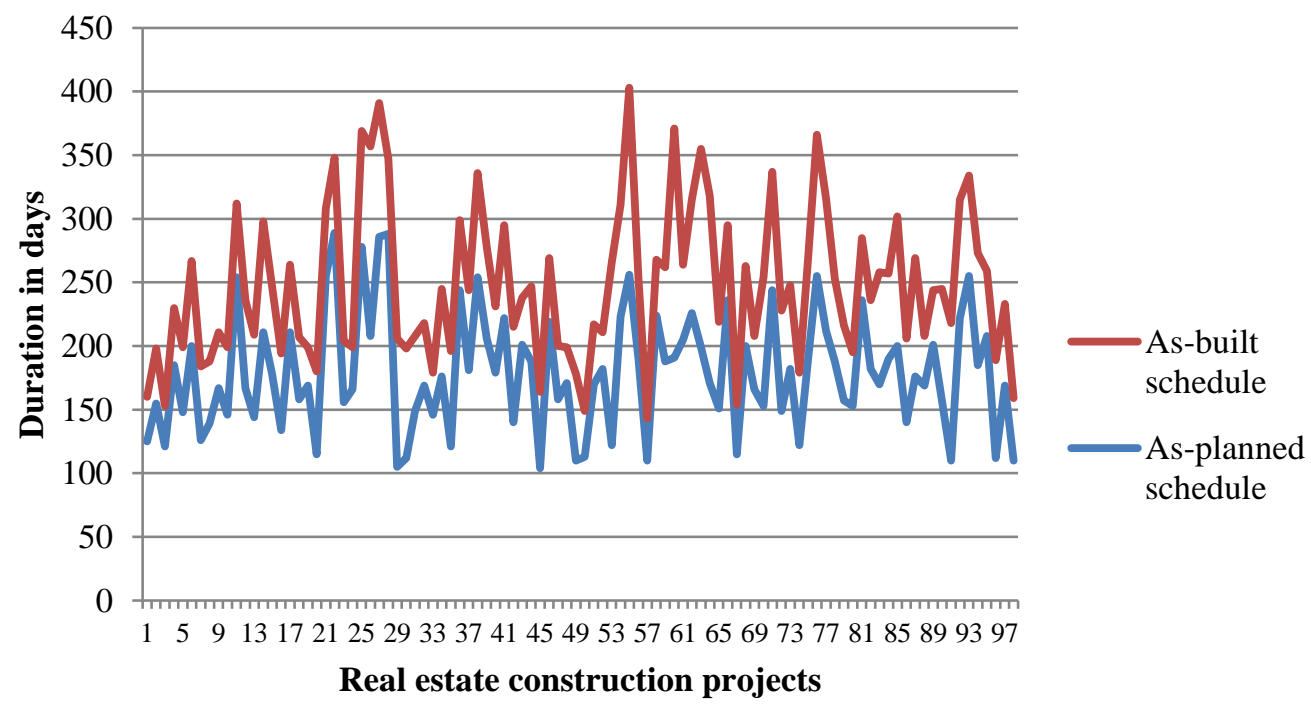

Fig. 1. Range of as-planned schedules with as-built schedules [figure made by authors]. 


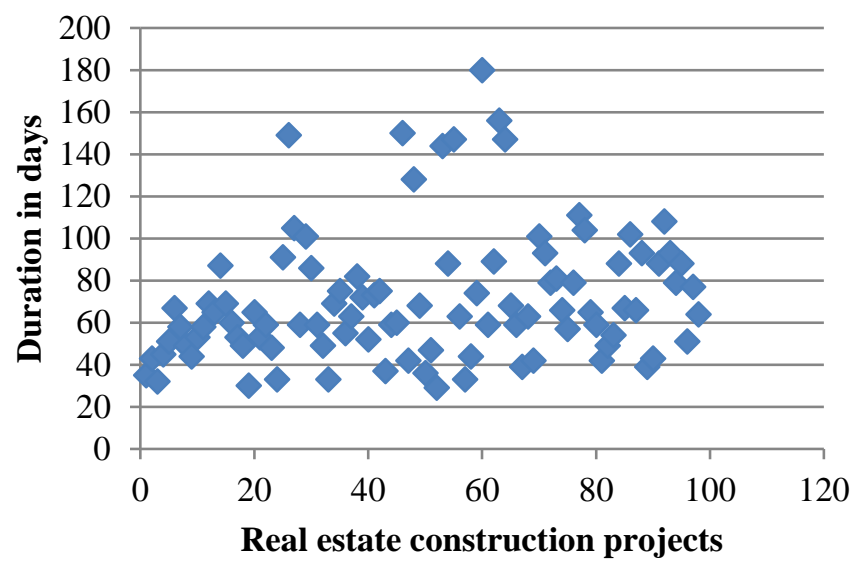

$\checkmark$ Time impact on as-planned schedule due to ingress of delays

Fig. 2. Time impact study [figure made by authors].

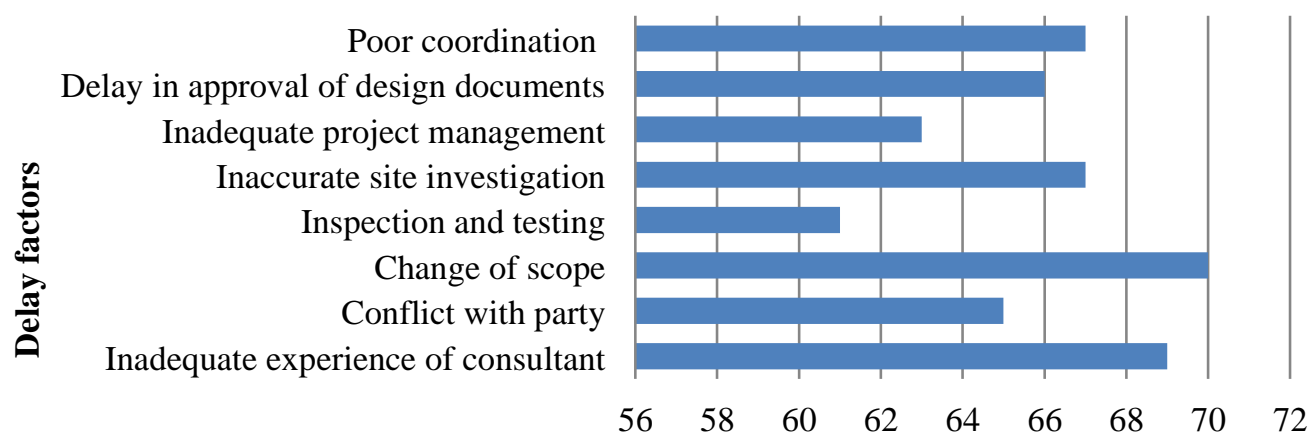

Frequency of occurrence in 100 real esate projects

- Consultant related factors

Fig. 3. Frequency of consultant-related delay factors [figure made by authors].

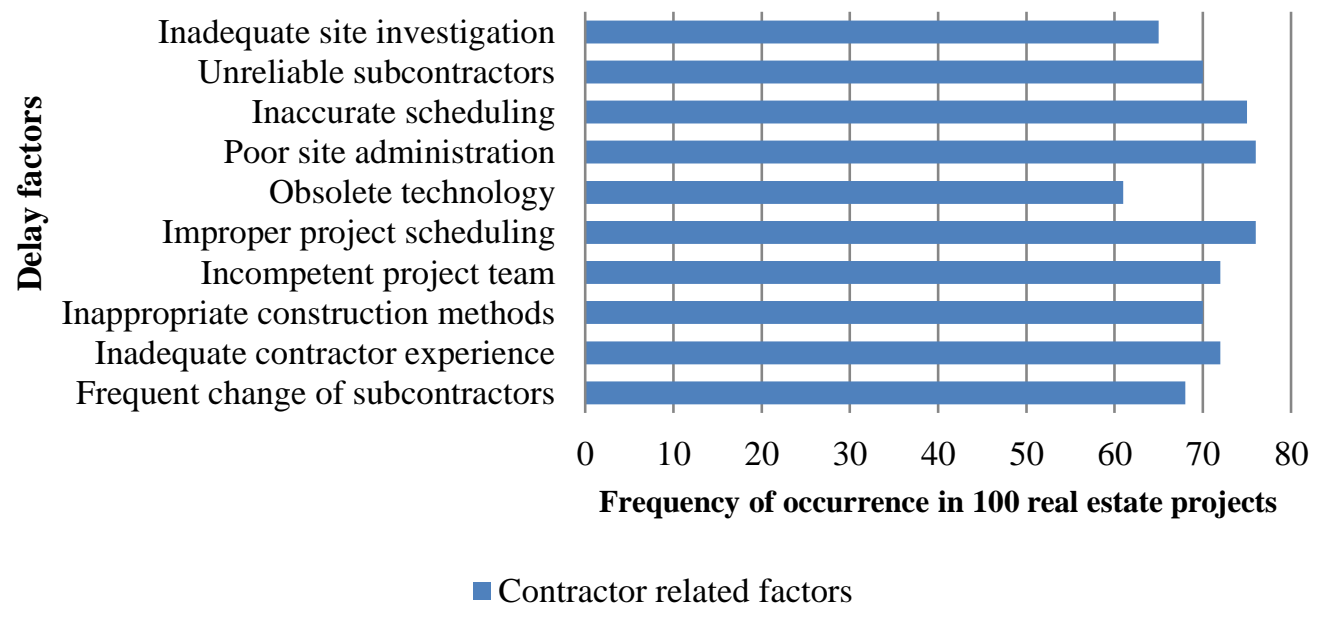

Fig. 4. Frequency of contractor-related delay factors [figure made by authors]. 
Incomplete project design

Unavailability of design software

Misunderstanding data by engineer Mistakes in design documents

Lack of design team experience

Insufficient survey data

Design errors and omissions

Design changes by owner

Complexity of project design

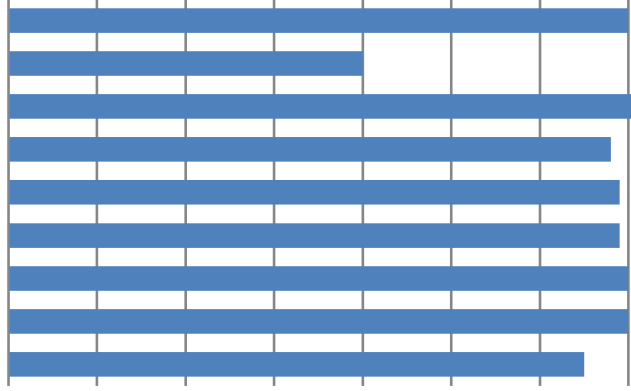

$\begin{array}{lllllllll}0 & 10 & 20 & 30 & 40 & 50 & 60 & 70 & 80\end{array}$

Frequency of occurrence in 100 real estate projects

\section{Design related factors}

Fig. 5. Frequency of design-related delay factors [figure made by authors].

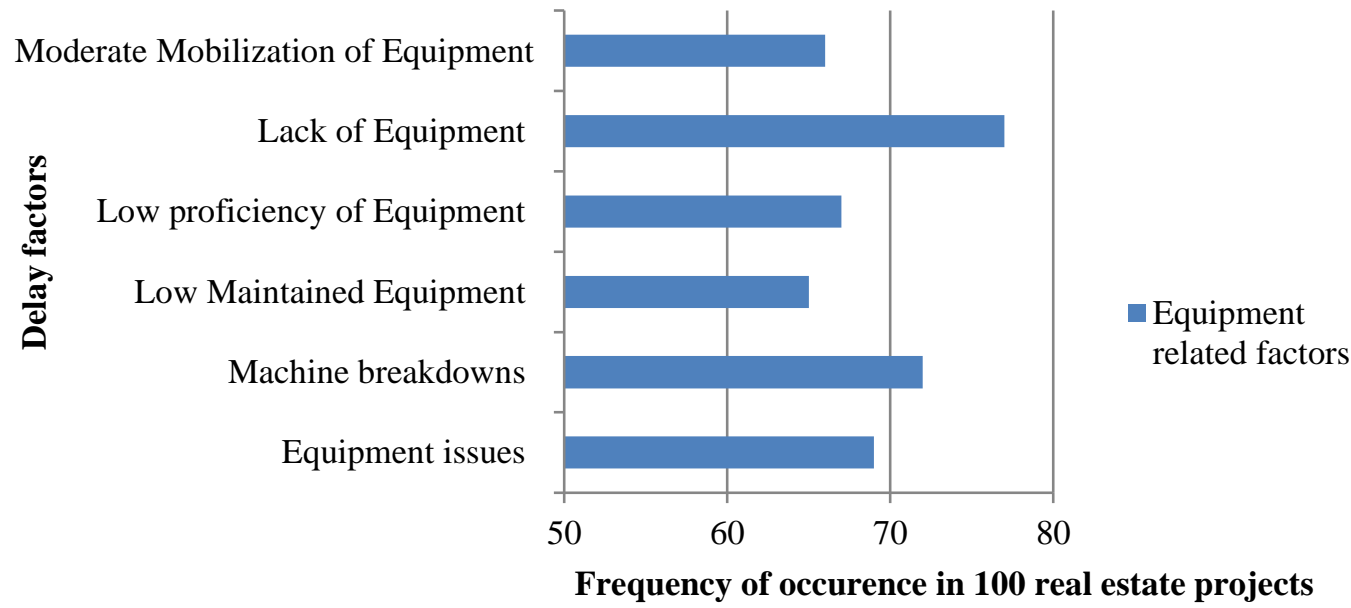

Fig. 6. Frequency of equipment-related delay factors [figure made by authors].

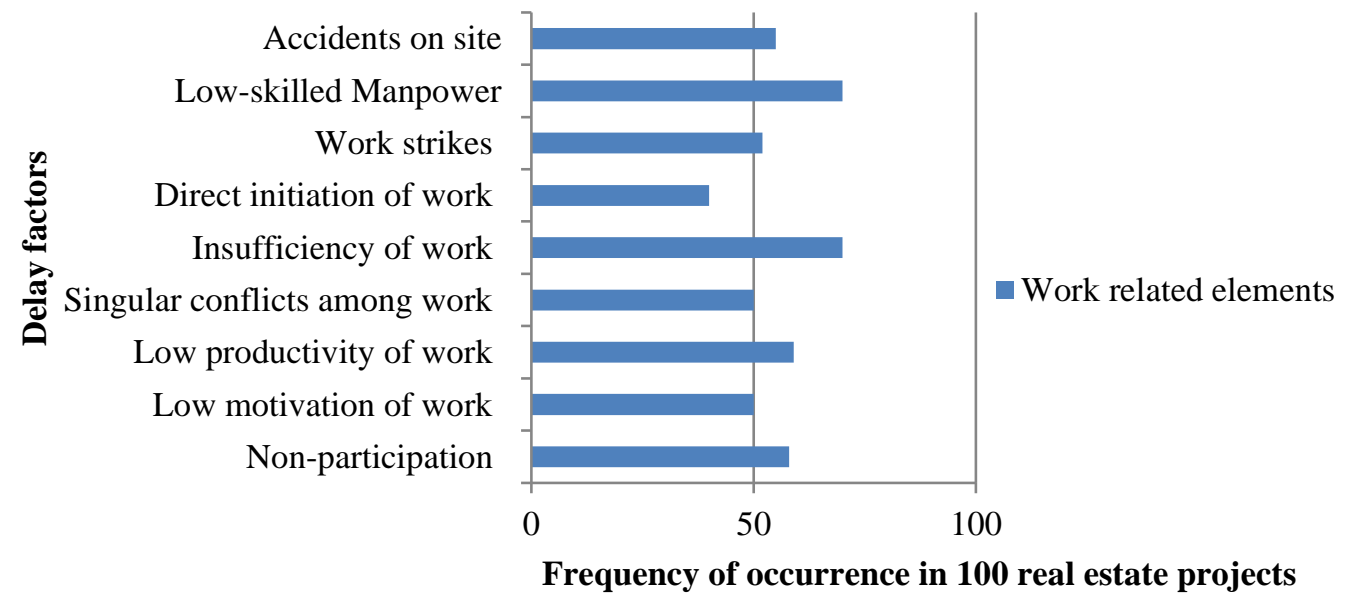

Fig. 7. Frequency of labour-related delay factors [figure made by authors]. 


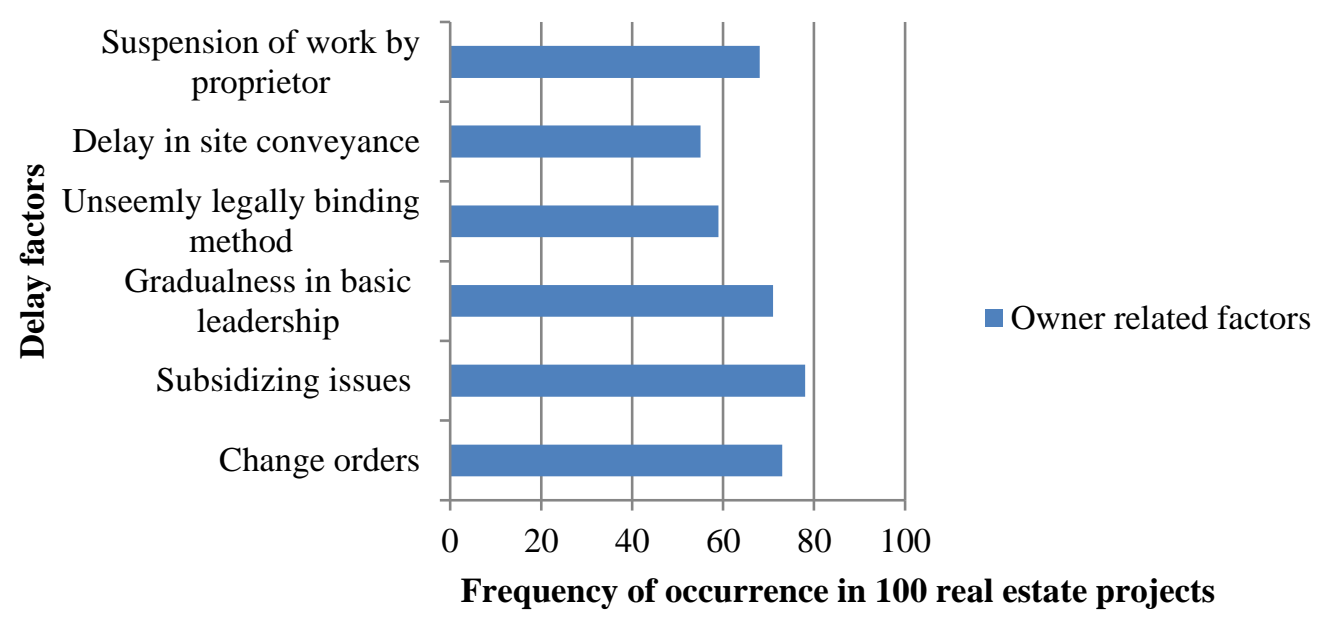

Fig. 8. Frequency of owner-related delay factors [figure made by authors].

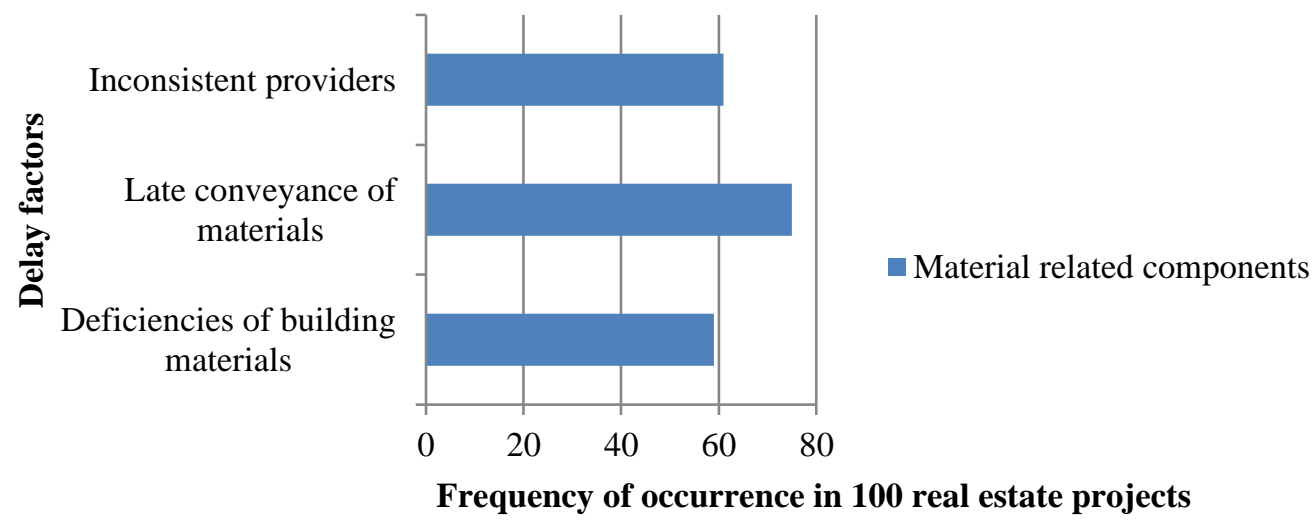

Fig. 9. Frequency of material-related delay factors [figure made by authors].

In conclusion, three components associated with material supply, deficiency and accessibility were identified in Figure 9.

\section{DATA ANALYSIS}

The RII was calculated by Chan and Kumaraswamy (2002) using the following formula:

$$
\mathrm{RII}_{k}^{i}(\%)=\frac{1 \times(n 1)+2 \times(n 2)+3 \times(n 3)+4 \times(n 4)+5 \times(n 5)}{5 \times(n 1+n 2+n 3+n 4+n 5)} \times 100
$$

where $\mathrm{RII}_{k}^{i}(\%)$ is the Relative Importance Index of each factor.

$n 1 ; n 2 ; n 3 ; n 4$; and $n 5$ are the numbers of each grouped respondents who selected " 1 " indicating next to no impact; " 2 " indicating little impact; " 3 " indicating normal impact; "4" indicating high impact and " 5 " indicating extreme impact.

The information gathered through polls was broken down with respect to relative significance (relative importance index - RII) as to the apparent significance and execution of Toyota Way standards. In view of the feedback 
received through survey from 275 respondents, the exact impact of every delay component was measured as "almost no", "little", "normal", "high" and "extreme". The scoring weight for these impacts was graded as 1,2,3,4, and 5. At that point utilizing the recipe of RII, the estimation of RII of the properties of every Toyota rule was conducted. The results are given in Table 2 .

Table 2. Statistics showing relative importance index of the attributes

\begin{tabular}{|c|c|c|}
\hline Characteristics of the Toyota Way Philosophy Model & RII & Rank \\
\hline Maintain a consistent reason (vision, mission, values) & 69.02 & 20 \\
\hline Have a mission, which is focused on stakeholders and customers & 64.58 & 33 \\
\hline Strategic project planning & 70.40 & 11 \\
\hline $\begin{array}{l}\text { Here and now misfortunes influence basic leadership, yet are less } \\
\text { essential than pursuing long haul objectives }\end{array}$ & 61.02 & 38 \\
\hline $\begin{array}{l}\text { Have an unmistakable perspective of the association's center } \\
\text { competency }\end{array}$ & 67.27 & 27 \\
\hline Oversee manageable items, designers, environment and society & 63.64 & 35 \\
\hline Understanding the client's pre-requisites is vital & 65.89 & 29 \\
\hline $\begin{array}{l}\text { Have the capacity to quickly react to meet the changing customer } \\
\text { requirements }\end{array}$ & 67.35 & 26 \\
\hline Treat representatives/providers as internal clients & 67.85 & 24 \\
\hline Job Security in worker's mind. & 72.29 & 8 \\
\hline Material should be available in sufficient quantity & 70.35 & 12 \\
\hline $\begin{array}{l}\text { Material, gear and different assets should be provided immediately } \\
\text { way when required }\end{array}$ & 72.44 & 7 \\
\hline $\begin{array}{l}\text { Site layout should be planned in such a manner that it facilitates } \\
\text { work flow. }\end{array}$ & 76.22 & 3 \\
\hline Free working environment should be ensured for human resource & 60.51 & 39 \\
\hline Make stream obvious through the hierarchical culture & 65.75 & 30 \\
\hline Inventory shall be located closer to the worksite & 76.07 & 4 \\
\hline $\begin{array}{l}\text { Make progress toward maintaining as low as feasible level of } \\
\text { material stock in the development site }\end{array}$ & 75.20 & 5 \\
\hline $\begin{array}{l}\text { Utilize basic signs cards, discharge containers, and so on to } \\
\text { monitor the level of stock and to arrange delivery of the required } \\
\text { materials }\end{array}$ & 70.25 & 13 \\
\hline Screen the amount of material/hardware that are rejected by groups & 64.65 & 32 \\
\hline $\begin{array}{l}\text { The project team should have complete knowledge of schedule, } \\
\text { material requirements, before starting execution. }\end{array}$ & 65.96 & 28 \\
\hline $\begin{array}{l}\text { Project Manager should ensure coordination amongst different } \\
\text { parties including subcontractors, suppliers and so forth. }\end{array}$ & 74.98 & 6 \\
\hline $\begin{array}{l}\text { Day by day work exercises are performed adjusting material } \\
\text { accessibility, labor, machine accessibility and workload between } \\
\text { operations }\end{array}$ & 64.58 & 33 \\
\hline
\end{tabular}




\begin{tabular}{|c|c|c|}
\hline Characteristics of the Toyota Way Philosophy Model & RII & Rank \\
\hline $\begin{array}{l}\text { The foreman takes responsibility for what the groups do every } \\
\text { week in considering the task that are on verge of completion }\end{array}$ & 69.75 & 15 \\
\hline $\begin{array}{l}\text { Week after week/daily work assignments are finished according to } \\
\text { weekly/day by day plan }\end{array}$ & 69.82 & 14 \\
\hline $\begin{array}{l}\text { Levelling the day by day work exercises without overburdening } \\
\text { specialists and hardware }\end{array}$ & 69.18 & 18 \\
\hline $\begin{array}{l}\text { Representatives are committed to complete the task ensuring } \\
\text { acceptable quality control }\end{array}$ & 68.73 & 22 \\
\hline Risk Assessment should be performed prior to execution & 68.36 & 23 \\
\hline Dismissing flawed materials, parts and gear & 70.69 & 10 \\
\hline $\begin{array}{l}\text { Representatives are motivated to look for support from their } \\
\text { administrators when something is not going as planned }\end{array}$ & 59.42 & 40 \\
\hline Representatives are enabled to oversee value creation & 64.29 & 34 \\
\hline $\begin{array}{l}\text { Representatives who work in a similar group meet all the time to } \\
\text { talk about quality issues and lessons learned }\end{array}$ & 69.53 & 16 \\
\hline $\begin{array}{l}\text { Set up standard working systems, e.g. work procedures are } \\
\text { polished by representatives for every significant procedure }\end{array}$ & 68.95 & 21 \\
\hline $\begin{array}{l}\text { Workers play the key role in maintaining standard operating } \\
\text { procedures }\end{array}$ & 69.16 & 19 \\
\hline $\begin{array}{l}\text { Workers are motivated to enhance the current standard operating } \\
\text { procedures in view of their own useful experience }\end{array}$ & 72.15 & 9 \\
\hline Utilizing institutionalized pre-assembled parts from off-site shops & 64.95 & 31 \\
\hline $\begin{array}{l}\text { Visual guides are employed to aware the worker about all pros and } \\
\text { cons, hazards that may affect activity at site }\end{array}$ & 61.31 & 37 \\
\hline $\begin{array}{l}\text { The posted data concerning occupation status, plan, quality, } \\
\text { security, and so forth is set up in the way that most workers can } \\
\text { see it regularly, and it is up-to-date }\end{array}$ & 67.42 & 25 \\
\hline $\begin{array}{l}\text { Suitable signage is utilized to provide information on designs, } \\
\text { movement, wellbeing concerns, and so on }\end{array}$ & 76.65 & 2 \\
\hline There should be no compromise with 5-S standards & 65.75 & 30 \\
\hline Innovation should promote the organization's performance & 56.00 & 41 \\
\hline Innovation should be made for specific methods & 63.35 & 36 \\
\hline $\begin{array}{l}\text { Innovation should be completely verified to ensure long haul } \\
\text { benefits }\end{array}$ & 77.82 & 1 \\
\hline Innovation must exhibit its capability to increase productivity & 69.24 & 17 \\
\hline
\end{tabular}

Source: developed by the authors, on the basis of Lean Construction Management (2014)

Table 2 showed the summarization of statistics results, showing relative importance index of the attributes. 


\section{EXPECTED BENEFITS IN POST DELAY MINIMIZATION}

A superior execution of the previously mentioned standards requires (1) as far as labour is concerned, that those employed in the subordinate stages of the progressive system know how the work can be done to add value to the superior procedure; (2) as far as materials and machines are concerned, that there is comprehension of how materials and machines ought to be dealt with keeping in mind the end goal to help individuals to apply better procedures and (3) as far as working environment is concerned, that those viewpoints, which influence working environment configuration, are included and upgrades are adopted at the project site (i.e. of design) to bring about superior procedures. Table 3 summarizes the discoveries.

Table 3. Preventive measures to lessen occurrence of delays

\begin{tabular}{|c|c|c|}
\hline Lean principles & Principles & $\begin{array}{l}\text { Benefits to reduce delay } \\
\text { causing factors }\end{array}$ \\
\hline $\begin{array}{l}\text { Long-term } \\
\text { philosophy }\end{array}$ & $\begin{array}{l}\text { Genuine cause } \\
\text { Have a strong cause or mission to create esteem } \\
\text { towards workers, society and clients } \\
\text { Acknowledgment of an organization's long-haul } \\
\text { vision } \\
\text { Short-term misfortunes influence basic leadership, } \\
\text { yet are less critical than the overall long-haul } \\
\text { objectives } \\
\text { Show substantial evidence of capabilities and } \\
\text { demonstrate expertise } \\
\text { Oversee items, workers and society } \\
\text { Understanding client's needs } \\
\text { Be ready to quickly react to meet the changing } \\
\text { customer needs (e.g. configuration change) } \\
\text { Treat representatives and providers as internal } \\
\text { clients } \\
\text { Expected results }\end{array}$ & $\begin{array}{l}\text { Ascribing more value to } \\
\text { workers, organizations, and } \\
\text { staff } \\
\text { Client satisfaction in terms of } \\
\text { quality and cost } \\
\text { Enhance safety of the } \\
\text { working environment } \\
\text { Give rise to value engineering } \\
\text { Long term relationships with } \\
\text { suppliers and subcontractors }\end{array}$ \\
\hline \multicolumn{3}{|c|}{ Inferences of Toyota way philosophy } \\
\hline One-piece flow & $\begin{array}{l}\text { Insecurity amongst workers } \\
\text { Material flow is reliable through the day by day } \\
\text { work exercises } \\
\text { Materials, hardware, and different assets are } \\
\text { supplied "just in time" way when required } \\
\text { Site design is arranged to improve material flow, } \\
\text { worker development, with a specific end goal to } \\
\text { limit squander } \\
\text { Free working environment should be ensured for } \\
\text { human resource } \\
\text { Make flow clear through authoritative culture }\end{array}$ & $\begin{array}{l}\text { Waste is disposed no matter } \\
\text { the volume } \\
\text { Continuous workflow is } \\
\text { ensured } \\
\text { Sufficient number of } \\
\text { labourers can be kept on the } \\
\text { stand-by } \\
\text { Materials are delivered to } \\
\text { base in JIT way } \\
\text { Administrators have solid } \\
\text { specialized know-how in } \\
\text { ensuring continuous work } \\
\text { process }\end{array}$ \\
\hline $\begin{array}{l}\text { Pull "Kanban" } \\
\text { system }\end{array}$ & $\begin{array}{l}\text { Material should be available in sufficient quantity } \\
\text { Strive for as low as conceivable levels of material } \\
\text { stock (even stockless) at the development site } \\
\text { Use straightforward signs - cards, discharge } \\
\text { containers, etc., to screen the level of stock and to } \\
\text { arrange the required materials or parts }\end{array}$ & $\begin{array}{l}\text { Low level of inventory at } \\
\text { project level } \\
\text { Good practice of material } \\
\text { stock management } \\
\text { Increased reliability of work } \\
\text { plans }\end{array}$ \\
\hline
\end{tabular}




\begin{tabular}{|c|c|c|}
\hline Lean principles & Principles & $\begin{array}{l}\text { Benefits to reduce delay } \\
\text { causing factors }\end{array}$ \\
\hline & $\begin{array}{l}\text { Monitor the amounts of materials, parts and } \\
\text { hardware that the groups really utilize } \\
\text { The project team should have complete knowledge } \\
\text { of schedule, material requirements, before starting } \\
\text { execution. }\end{array}$ & $\begin{array}{l}\text { Enhanced ability in shielding } \\
\text { the downstream work } \\
\text { Cost control of building } \\
\text { materials }\end{array}$ \\
\hline $\begin{array}{l}\text { Level out the } \\
\text { workload }\end{array}$ & $\begin{array}{l}\text { The venture director arranges the work with } \\
\text { contributions from different parties, including } \\
\text { subcontractors, customers and suppliers } \\
\text { Daily work exercises are adjusted considering } \\
\text { material accessibility, labour, machine } \\
\text { accessibility and distributing workload between } \\
\text { operations } \\
\text { The foreman takes responsibility for what the } \\
\text { groups do every week in considering the task that } \\
\text { are on verge of completion Weekly and every day } \\
\text { work assignments are finished according to weekly } \\
\text { and day by day plans } \\
\text { Levelling the everyday work exercises without } \\
\text { overburdening specialists and hardware }\end{array}$ & $\begin{array}{l}\text { Improved coordinated effort } \\
\text { between venture groups and } \\
\text { different venture partners } \\
\text { Strengthen coordination } \\
\text { amongst contracting parties } \\
\text { Enhancement of foremen's } \\
\text { aptitudes in employment } \\
\text { arrangement } \\
\text { Less possibility of time } \\
\text { extension }\end{array}$ \\
\hline Built-in quality & $\begin{array}{l}\text { Employees are devoted to deliver quality } \\
\text { "inherent" in each operation } \\
\text { Preventing faulty or "no review" assignments from } \\
\text { entering the following procedure } \\
\text { Rejecting faulty materials, parts, and hardware } \\
\text { Representatives are motivated to look for support } \\
\text { from their administrators when something is not } \\
\text { going as planned Employees are enabled to be in } \\
\text { charge of value } \\
\text { Employees who work in a similar group regularly } \\
\text { meet to talk about quality issues and lessons } \\
\text { learned } \\
\text { Feedback about quality is routinely given by } \\
\text { workers }\end{array}$ & $\begin{array}{l}\text { Improved quality: reduction } \\
\text { of the number of redone tasks } \\
\text { and less frequently } \\
\text { reoccurring quality issues } \\
\text { Improved aptitudes in } \\
\text { distinguishing issues } \\
\text { Giving specialists authority to } \\
\text { stop the operation if an issue } \\
\text { happens } \\
\text { Improved cooperation and } \\
\text { correspondence associated } \\
\text { with quality change }\end{array}$ \\
\hline Standardization & $\begin{array}{l}\text { Established standard working techniques (e.g. } \\
\text { work procedures) are drilled by representatives for } \\
\text { every significant action and procedure } \\
\text { Staff play a key role in drawing up the work plan } \\
\text { Staff are motivated to enhance the current SOPs in } \\
\text { light of their own experience } \\
\text { Incorporate workers' innovative changes of the } \\
\text { standard into new SOPs } \\
\text { Use institutionalized pre-assembled parts from } \\
\text { offsite yards }\end{array}$ & $\begin{array}{l}\text { Improved comprehension of } \\
\text { institutionalization } \\
\text { Improved profitability } \\
\text { ensured by } \\
\text { institutionalization } \\
\text { Improved responsibility for } \\
\text { operations } \\
\text { More institutionalized } \\
\text { segments or materials can be } \\
\text { presented and utilized }\end{array}$ \\
\hline $\begin{array}{l}\text { Visual } \\
\text { management }\end{array}$ & $\begin{array}{l}\text { Visual guides are employed to aware the worker } \\
\text { about all pros and cons, hazards that may affect } \\
\text { activity at site } \\
\text { The information on business status, arrangements, } \\
\text { quality, safety concerns, etc., appears in a place } \\
\text { that most stakeholders can see once every day } \\
\text { Suitable signage is used to inform on plans, } \\
\text { movement flow, and occupational safety concerns } \\
\text { and so forth. } \\
\text { The development site is kept in good condition at } \\
\text { all times } \\
\text { Employees are appreciated in keeping the } \\
\text { construction site sorted out }\end{array}$ & $\begin{array}{l}\text { Increased utilization of visual } \\
\text { apparatuses } \\
\text { Higher consciousness of the } \\
\text { 5-S program and more } \\
\text { comprehensive interest } \\
\text { More composed and tidier } \\
\text { site } \\
\text { Staff are trained to keep the } \\
\text { site clean }\end{array}$ \\
\hline
\end{tabular}




\begin{tabular}{|l|l|l|}
\hline Lean principles & Principles & $\begin{array}{l}\text { Benefits to reduce delay } \\
\text { causing factors }\end{array}$ \\
\hline $\begin{array}{l}\text { Use of reliable } \\
\text { technology }\end{array}$ & $\begin{array}{l}\text { Innovation should promote the organization's } \\
\text { performance } \\
\text { Innovation should be made for specific methods } \\
\text { Innovation should be specific arrangement situated } \\
\text { Innovation should be approbated to ensure long } \\
\text { haul benefits }\end{array}$ & $\begin{array}{l}\text { Development of an efficient } \\
\text { working framework and is } \\
\text { implementation to different } \\
\text { segments of an organization } \\
\text { for performance enhancement } \\
\text { Improved comprehension of } \\
\text { clients and clients values } \\
\text { Improved consumer loyalty } \\
\text { Increased intensity }\end{array}$ \\
& & $\begin{array}{l}\text { Additional incentives to } \\
\text { representatives, firms, and } \\
\text { society on the whole }\end{array}$ \\
\hline
\end{tabular}

Source: developed by the authors, on the basis of Lean Construction Management (2014)

Table 3 showed the summarization of main preventive measures to lessen occurrence of delays.

\section{CONCLUSION}

Implementing a time impact analysis of the affected real estate construction can be challenging (Nesensohn et al., 2012). Highest ranked lean characteristic verifies the idea that new innovations provide long term benefits. Respondents think that implementation of innovations in real estate construction projects can beneficial. The Toyota Way postulates are practiced with the aim to bridge the gap between the working practices that contemporarily prevail in India and lean construction principles. It is forecasted to enable real estate construction firms to organize and schedule their construction projects more systematically from the beginning to the end.

The research findings indicate that necessity of application of Toyota way characteristics but also provide a layout of execution in an unbiased manner. Hence, it likewise offers procedures for applying them successfully. This framework can be utilized by the top administration of the organization, as it provides the basis for initiating hierarchical culture changes. Overall, this research can be used as a practical recommendation covering a number of areas, including corporation ideology, working procedures, team and teammate management, and dealing with challenges.

\section{REFERENCES}

Alaghbari, W., Razali A. Kadir, M., Salim, A., \& Ernawati. (2007). The significant factors causing delay of building construction projects in Malaysia. Engineering, Construction and Architectural Management, 14(2), 192-206. https://doi.org/10.1108/09699980710731308

Al-Khalil, M. I., \& Al-Ghafly, M. A. (1999). Important causes of delay in public utility projects in Saudi Arabia. Construction Management and Economics, 17(5), 647-655. https://doi.org/10.1080/014461999371259

Al-Momani, A. H. (2000). Construction delay: a quantitative analysis. International Journal of Project Management, 18(1), 51-59. https://doi.org/10.1016/s0263-7863(98)00060-x

Arditi, D., Akan, G. T., \& Gurdamar, S. (1985). Reasons for delays in public projects in Turkey. Construction Management and Economics, 3(2), 171-181. https://doi.org/10.1080/01446198500000013 
Arditi, D., \& Robinson, M. A. (1995). Concurrent Delays in Construction Litigation. Cost Engineering Journal, AACE International, 37(7), 20-31.

Asim, M., Deep, S., \& Dr. Aqeel, S. A. (2017). Time Impact Study of Real Estate Sector Construction Projects Post Application of Lean Principles for Delay Resolutions. International Journal of Civil Engineering and Technology, 8(2), 89-99.

Assaf, S. A., \& Al-Hejji, S. (2006). Causes of delay in large construction projects. International Journal of Project Management, 24(4), 349-357. https://doi.org/10.1016/j.ijproman.2005.11.010

Assaf, S. A., Al-Khalil, M., \& Al-Hazmi, M. (1995). Causes of Delay in Large Building Construction Projects. Journal of Management in Engineering, 11(2), 45-50. https://doi.org/10.1061/(asce)0742-597x(1995)11:2(45)

Baldwin, J. R., Mathei, J. M., Rothbart, H., \& Harris, R. B. (1971). Causes of Delay in the Construction Industry. Journal of Construction Division, 97(2), 177-187.

Barker, R., Childerhouse, P., Naim, M., Masat, J., \& Wilson, D. (2004). Potential of Total Cycle Time Compression in Construction: Focus on Program Development and Design. Journal of Construction Engineering and Management, 130(2), 177-187. https://doi.org/10.1061/(ASCE)0733-9364(2004)130:2(177)

Chang, A. S., Shen, F.-Y., \& Ibbs, W. (2010). Design and construction coordination problems and planning for design-build project new users. Canadian Journal of Civil Engineering, 37(12), 1525-1534. https://doi.org/10.1139/110-090

Deep, S., Singh, D., \& Ahmad, S. A. (2017). A Review of Contract Awards to Lowest Bidder in Indian Construction Projects via Case Based Approach. Open Journal of Business and Management, 05(01), 159-168. https://doi.org/10.4236/ojbm.2017.51015

Dlakwa, M. M., \& Culpin, M. F. (1990). Reasons for overrun in public sector construction projects in Nigeria. International Journal of Project Management, 8(4), 237-241. https://doi.org/10.1016/0263-7863(90)90032-7

Doloi, H., Sawhney, A., Iyer, K. C., \& Rentala, S. (2012). Analysing factors affecting delays in Indian construction projects. International Journal of Project Management, 30(4), 479-489. https://doi.org/10.1016/j.ijproman.2011.10.004

Etges, B., Saurin, T. A., \& Bulhões, I. R. (2012). "Identifying lean construction categories of practices in IGLC proceedings." Proc., 20th Annual Conf. of the Int. Group for Lean Construction, International Group for Lean Construction (IGLC), Oslo, Norway

Gao, S. \& Low, S. P. (2014). Lean Construction Management. http://dx.doi.org/10.1007/978-981-287$\underline{014-8}$

Gibson, G. E., Wang, Y.-R., Cho, C.-S., \& Pappas, M. P. (2006). What Is Preproject Planning, Anyway? Journal of Management in Engineering, 22(1), 35-42. https://doi.org/10.1061/(asce)0742-597x(2006)22:1(35)

Gonzalez, V., Alarcon, L. F., \& Mundaca, F. (2008). Investigating the relationship between planning reliability and project performance. Production Planning \& Control, 19(5), 461-474. https://doi.org/10.1080/09537280802059023

Hanna, A. S., \& Skiffington, M. A. (2010). Effect of Preconstruction Planning Effort on Sheet Metal Project Performance. Journal of Construction Engineering and Management, 136(2), 235-241. https://doi.org/10.1061/(asce)0733-9364(2010)136:2(235)

Kazaz, A., Ulubeyli, S., \& Tuncbilekli, N. A. (2012). Causes of Delays in Construction Projects in Turkey. Journal of Civil Engineering and Management, 18(3), 426-435. https://doi.org/10.3846/13923730.2012.698913

LCI. (2013). "Lean project design and delivery in action." Retrieved May 10, 2013, from http://www.leanconstruction.org/.

LCI. (2014). "LCI lean project delivery glossary." Retrieved May 12, 2014, from http://www.leanconstruction.org.

LCI. (2015). "What is lean design and construction?" Retrieved May 20, 2015, from http://www.leanconstruction.org/.

Lovejoy, V. A. (2004). Claims Schedule Development and Analysis: Collapsed As-built Schedule for Beginners. Cost Engineering Journal, AACE International, 46(1), 27-30.

Lowsley, S., \& Linnett, C. (2006). About Time: Delay Analysis in Construction. RICS Business Services Limited. 
Iyer, K. C., \& Jha, K. N. (2006). Critical Factors Affecting Schedule Performance: Evidence from Indian Construction Projects. Journal of Construction Engineering and Management, ASCE, 132(8), 871-881.

Nesensohn, C., Demir, S. T., \& Bryde, D. J. (2012). "Developing a 'true north' best practice lean company with navigational compass." Proc., 20th Annual Conf. of the Int. Group for Lean Construction, International Group for Lean Construction (IGLC), Oslo, Norway.

Thomas, H. R., \& Ellis, R. D. (2007). Contractor Prebid Planning Principles. Journal of Construction Engineering and Management, 133(8), 542-552. https://doi.org/10.1061/(asce)07339364(2007)133:8(542)

Yang, J.-B., \& Wei, P.-R. (2010). Causes of Delay in the Planning and Design Phases for Construction Projects. Journal of Architectural Engineering, 16(2), 80-83. https://doi.org/10.1061/(asce)10760431(2010)16:2(80)

Yang, L.-R., Chen, J.-H., \& Huang, C.-F. (2012). Requirements Definition and Management Practice to Improve Project Outcomes. Journal of Civil Engineering and Management, 18(1), 114-124. https://doi.org/10.3846/13923730.2012.657340

\section{AUTHORS' SHORT BIOGRAPHIES}

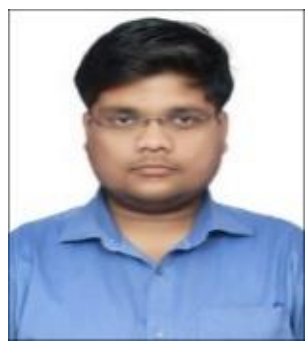

Shumank Deep is a Research Scholar at School of Architecture and Built Environment, University of Newcastle, Callaghan NSW, Australia. His research interests include construction delays, procurement process of construction projects, lean construction management, equipment management, supply chain management.

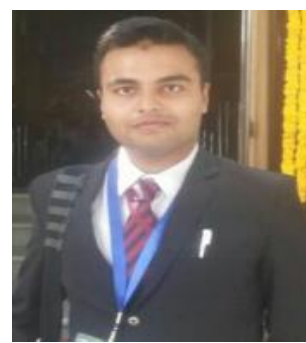

Mohd Asim is a postgraduate scholar at the Department of Civil Engineering, Integral University. He obtained Professional Bachelor Degree with honours in Civil Engineering and awarded gold medal for M. Tech (Construction Technology and Management). His research interests include real-estate construction projects delays, sustainable construction, construction equipment maintenance, lean construction management.

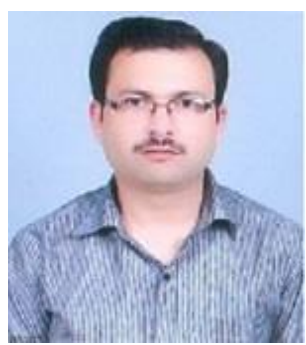

Mohd Kashif Khan is an Associate Professor at the Department of Civil Engineering, Integral University, Lucknow, UP, India. His research interests include structural engineering, structural health monitoring, construction costing, and valuation of property. 